\title{
Shorebird Paradise
}

\author{
by Edgar T. Jones, Edmonton.
}

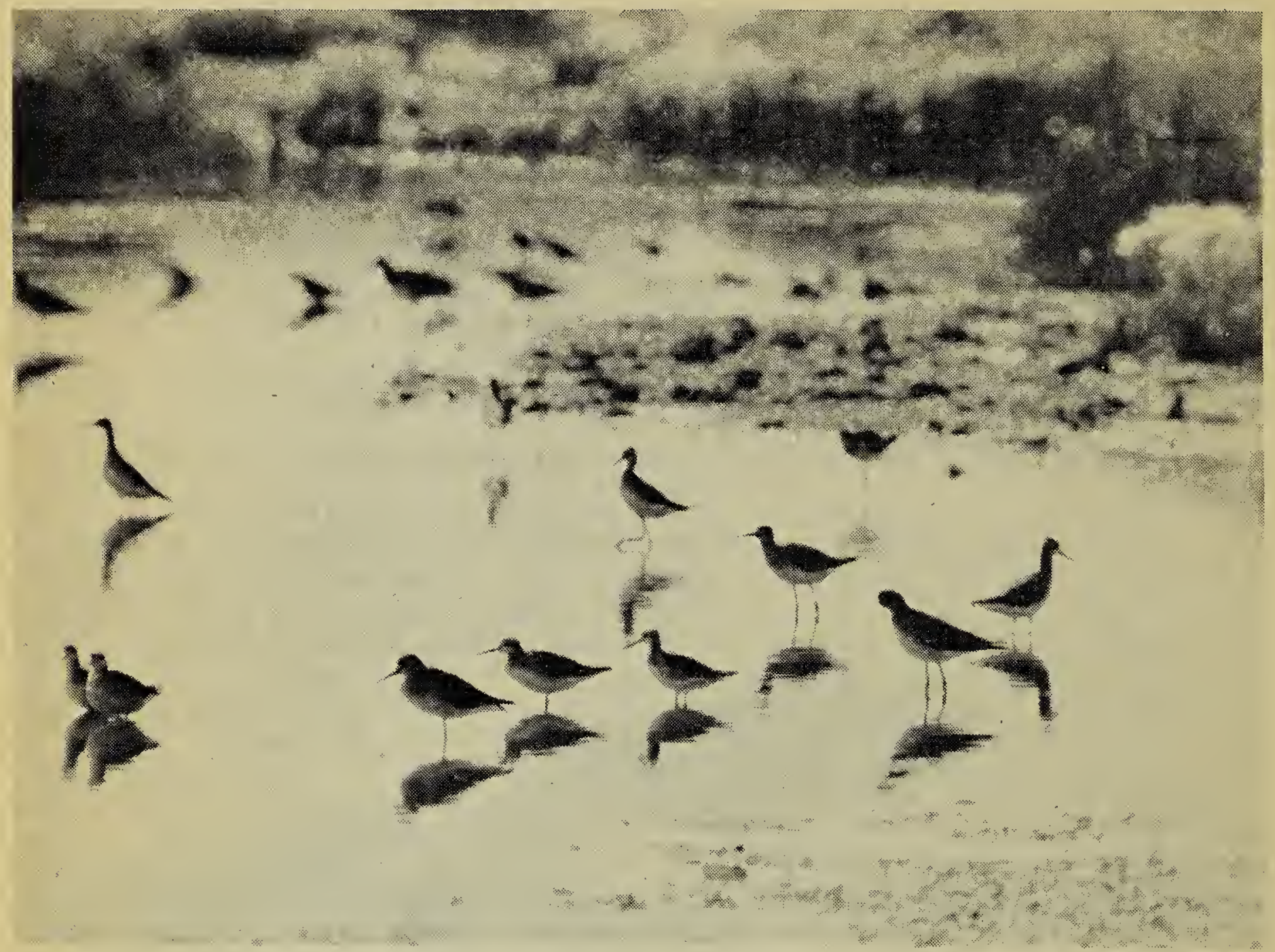

Photo by $\mathrm{Cy}$ Hampson

A flight of shore birds settles on a muddy flat.

Saskatchewan; like Alberta, has, I am sure, some outstanding places where large, varied concentrations of migrating birds gather on their way to their breeding grounds. Such a place in Alberta is Beaverhill Lake, just 50 miles east of Edmonton near one of our main highways. This large shallow lake (it is no deeper than six feet anywhere) has since time immemorial been a major stopping place for thousands upon thousands of migrating shorebirds.

The late Dr. William Rowan, well known for his many scientific studies of birds, spent many of his collecting days camped on the shores of this unique lake. In those days a long, low-lying point jutted almost two miles out into the lake, creating a shallow bay at the south end of the lake, a veritable paradise for waders! Dr. Rowan's accounts of the myriads of $\mathrm{shorebirds}$ passing through this area in days gone by make fascinating reading for anyone who has any interest in shorebird migration.

Today this lake, due to a gradual drying up, has lost its fabulous Francis Point, but nevertheless it still has a great attraction for birds. The mud and sand flats along the shoreline attract huge flocks of Northern Phalarope, Baird's and Pectoral Sandpipers, along with hordes of the smaller "peeps." Here, too, may be seen the less common waders-White-rumped Sandpipers, Hudsonian Godwits, Black-bellied Plover, Knots, Dunlin, Buff-breasted Sandpipers, Greater Yellowlegs and many others. The procession is steady for at least two weeks during the latter part of May. As flocks move on north, around the first week in June, the supply dwindles and the northward migration is through for another year. To give an idea of the variety to be encountered here, I 
cite the following extract from my log of two days' observations, May 23 and 24, 1957. No fewer than 22 species were recorded, some of them real rarities! They included: Killdeer (several), American Golden Plover (15), Black-bellied Plover (32), Ruddy Turnstone (52), Common Snipe (1), Long-billed Curlew (1) (rare), Whimbrel (23) (rare), Willet (several), Lesser Yellowlegs (numerous), Knot (28), Pectoral Sandpiper (numerous), B a ir d's Sandpiper (numerous), Least Sandpiper (numerous), L o n g - b i l l e d Dowitcher (100), Stilt Sandpiper (150), Semipalmated S a n d p i p e r (numerous), Buff-Breasted Sandpiper (27) (rare), Marbled Godwit ( 5 nests, each with 4 eggs), Sanderling (numerous), American Avocet (2 nests, 7 and 4 eggs), Wilson's Phalarope (5), Northern Phalarope (100 plus).

After a brief period on their Arctic breeding grounds the shorebirds again head southward. As early as July 15 the procession begins. For some rea- son the southward movement seems to be much more staggered and, as a result, the numbers of birds seen at one time considerably smaller. However, the following extract from my $\log$ of July 27 gives some idea of what to expect: Semipalmated Plover (35), Killdeer (7), Black-bellied Plover (15), Willet, Greater Yellowlegs (4), Lesser Yellowlegs (12), Pectoral Sandpiper (8), White-rumped Sandpiper (3) (rare), Baird's Sandpiper (10), Least Sandpiper (5), Long-billed Dowitcher (50 ṕlus), Stilt Sandpiper (2), Semipalmated Sandpiper (numerous), Marbled Godwit, Hudsonian Godwit (1), Sanderling (5), Wilson's Phalarope (20 plus), Northern Phalarope (60).

To the amateur Beaverhill Lake offers a fascinating opportunity to compare and learn the numerous species of waders. To the experienced ornithologist, it is a place where anything can turn up, and usually does! May the day never come when the plough turns the sod of Beaverhill Lake.

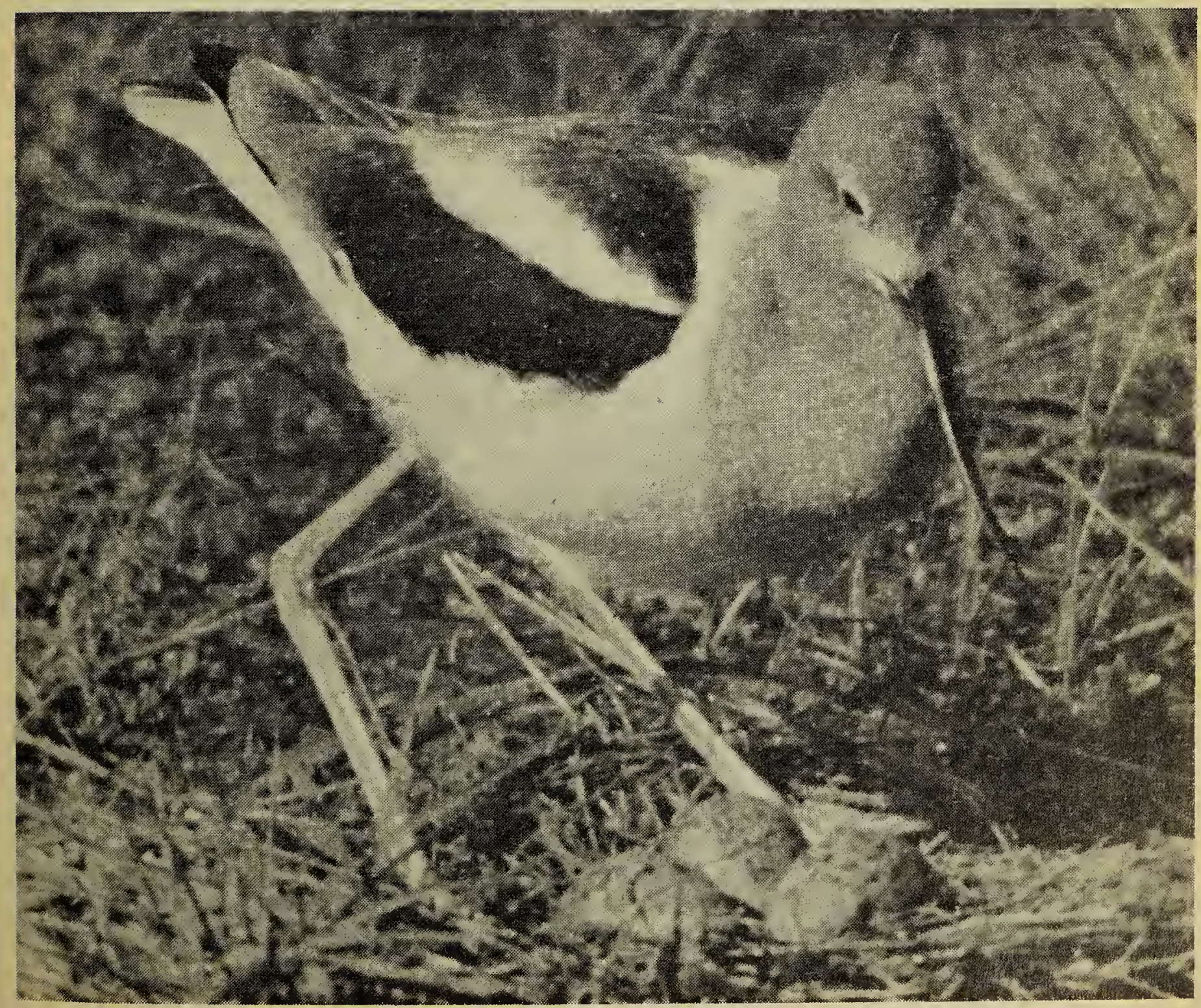

A colourful Avocet settles over its eggs This beautiful shorebird is one of the breeding residents of Beaverhill Lake: every year a few pairs nest here in what is undoubtedly one of the most northerly breeding areas in Alberta. 